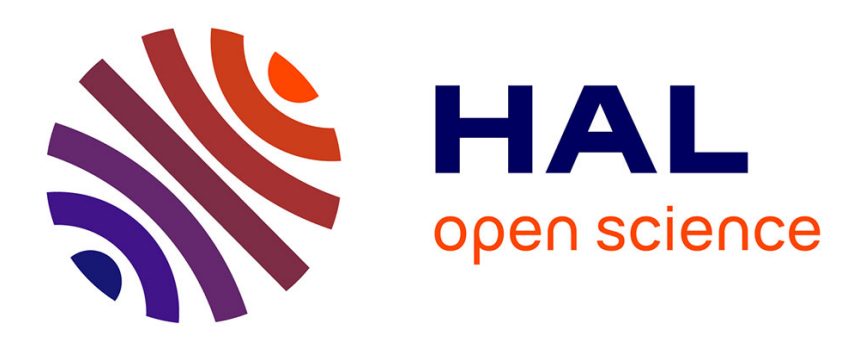

\title{
Happy Christmases are all alike; each unhappy Christmas is unhappy in its own way
}

Vivien Blanchet

\section{To cite this version:}

Vivien Blanchet. Happy Christmases are all alike; each unhappy Christmas is unhappy in its own way. Marketing Theory, 2020, FORTH, 10.1177/1470593119897764 . hal-02437257

\section{HAL Id: hal-02437257 https://hal.science/hal-02437257}

Submitted on 13 Jan 2020

HAL is a multi-disciplinary open access archive for the deposit and dissemination of scientific research documents, whether they are published or not. The documents may come from teaching and research institutions in France or abroad, or from public or private research centers.
L'archive ouverte pluridisciplinaire HAL, est destinée au dépôt et à la diffusion de documents scientifiques de niveau recherche, publiés ou non, émanant des établissements d'enseignement et de recherche français ou étrangers, des laboratoires publics ou privés. 
archives-ouvertes

\section{Happy Christmases are all alike; each unhappy Christmas is unhappy in its own way}

Vivien Blanchet

\section{To cite this version:}

Vivien Blanchet. Happy Christmases are all alike; each unhappy Christmas is unhappy in its own way. Marketing Theory, 2020. hal-02437257

\section{HAL Id: hal-02437257 \\ https://hal.archives-ouvertes.fr/hal-02437257}

Submitted on 13 Jan 2020

HAL is a multi-disciplinary open access archive for the deposit and dissemination of scientific research documents, whether they are published or not. The documents may come from teaching and research institutions in France or abroad, or from public or private research centers.
L'archive ouverte pluridisciplinaire HAL, est destinée au dépôt et à la diffusion de documents scientifiques de niveau recherche, publiés ou non, émanant des établissements d'enseignement et de recherche français ou étrangers, des laboratoires publics ou privés. 


\title{
Happy Christmases are all alike; each unhappy Christmas is unhappy in its own way
}

\author{
Vivien Blanchet $\mathbb{1}$ \\ Emlyon Business School, France
}

\begin{abstract}
The French postal service has been opening a bureau for Father Christmas every winter since 1962. Sixty employees are responsible for responding to letters to Father Christmas. In 2018, more than one million children corresponded with him. But what would happen if someone were to write to Father Christmas, developing a close epistolary relationship with him? This short story explores such a scenario. Pierre M. and Father Christmas have during many years maintained regular and personal correspondence. Yet Father Christmas's attitude seems to have changed. Pierre M. reveals the evolution of their secret relationship to his mysterious friend. On substance, the short story offers an original perspective on modern marketplace mythologies. Previous studies depict myths as liminal spaces in which people negotiate contradictory meanings, practices and realities. The myth of Father Christmas thus involves compromises between ignorance and knowledge, life and death, the sacred and the profane. The short story tells how they evolve to define the identity of the protagonists and the world they live in. It highlights how they are embodied in hybrid artefacts like letters to Father Christmas and extraordinary servicescape. The short story also questions the performative force of the myth. It shows that it results from the interpretative work and ritual practices of the protagonists involved in an unstable actantial system structured around an enlightened person, an ignorant person and a mythical character. This is constantly negotiated throughout sociotechnical interactions, which, as in the case of witchcraft, may or may not realize the myth. On form, the short story adopts the principle of the eternal return inherent to the myth: it is plotted as a series of small variations on recurring themes and structural repetitions. Intertextual references to academic publications, literary tradition and popular culture enrich the narrative by extending it beyond its textual boundaries.
\end{abstract}

\section{Keywords}

Christmas, discourse, marketplace mythology, myth, performativity, Santa Claus 
My very dear friend,

I must leave. Will I be allowed to see you again? I don't know. I wanted to let you know in person the other day, just after the incident. For the last time, I left my post near the galleon, headed for the castle, went through the labyrinth and around the carousel and found you on the esplanade, accompanied by your golden dog and surrounded by a crowd of children. You were distributing balloons and sweets. You were laughing, as were the children. I approached. You saw me and waved. It was then I understood: 'Pierrot, mon ami, I see you; I cannot come and greet you, but rest assured you have my sincerest friendship'. I smiled tenderly. You have so much love to give.

It's a rare quality, one I thought I had detected in a man once. But my disappointment matched my hope. I loved that man as I would a father, and he in return loved me as a son-or so I thought. Why have I never told you about him? Out of discretion: he's a celebrity whom many people would like to include among their close acquaintances, but he chose me over everybody else; it is a privilege that I preferred not to share so as to protect our relationship from envious outsiders. But, today, I admit to you that Father Christmas and I have for many years maintained regular correspondence.

It all began on 6 December 199-. The idea came from Mum. I was 6 years old. She asked me to write to Father Christmas. He was her friend. We wrote the letter together:

Deer Father Christmas,

I am very gud to mummy and daddy. I'm riting to you so I can get prezents. I'd like a Winnie the Poo tedy bear, a blak K2000 car, a sherif's costume, marbels, the Littel Mermaid tape and a jigsaw with dogz. I also luv sweets even though I no their not gud for my teeth.

I hope you won't forgett me.

Hugs and kisses,

Pierrot

Father Christmas wrote back to me 2 weeks later. I've retrieved the letter from my box of treasures. It's a bit wrinkled, torn on the left edge and stained here and there; but even if the ink vanished I could still recite it word for word:

My dear child,

Thank you for your lovely letter and list of gift requests.

I say, you are asking for rather a lot this year! Fortunately, my elves tell me that you have been a good boy (except for a few small misdeeds... which I forgive you).

My elves and I are therefore busy preparing lots of wonderful surprises for you. But Ho-Ho-Ho! I hear

them calling me. I'll leave you there. I must help them prepare the presents.

Keep being a good little boy, working hard at school and making your parents happy.

I wish you a happy Christmas, my child.

Father Christmas

Father Christmas used to receive millions of letters! From children all over the world! But he chose to reply to me, Pierre, just 6 years old! And not just any old reply! His words were so gentle, warm and affectionate. "My child... my dear child"... I was like a family member - the son he had never had perhaps. His elves kept a watchful eye over me-their way of protecting me. He promised to shower me with surprises; and he kept his word: I remember the presents laid at the foot of the Christmas tree, my excitement unwrapping them, and the joy I felt as I discovered the items I so desired. 
I paid dearly for my happiness. The year that followed was a difficult one. In the heat of the excitement, I boasted to my schoolmates of my wonderful correspondence. It did not go down well. I became the victim of their childish jealousy and unkindness. They called me a liar and an idiot and spent the whole year mocking and teasing me. When I wasn't the target of their villainy, they turned on my illustrious friend, insulting Father Christmas and claiming that he didn't exist, that he was no more than a fabrication dreamt up as part of a conspiracy between grown-ups; some even accused my parents of being complicit. I suffered greatly at the hands of my classmates. I forgive them now. I know that such conspiracy theories have their supporters and that there are similar theories about the Tooth Fairy, the Easter Bunny, the Sandman and Hans Trapp. I have no doubt that my young classmates were simply repeating the ridiculous views of their parents. But a child cannot be held responsible for the idiocy of grown-ups, isn't that right? I wasn't so sure at the time. The other children's mockery affected me. I began to doubt. And so it was not without anxiety that, on the following year, I wrote to Father Christmas. My mother helped me; I remember going to post the letter with her:

\footnotetext{
Deer Father Christmas,

Thank you for your prezents, which were really grate. I've worked hard at skool. I'd like a pistel, a fake one not a reel one, a poleesman costume like on the telly, a fire enjin with a siren, the Bewty and the beest tape and Playmobil Indians. You can giv me sweets too becuz my Mum never wants to by any becuz she sez they rot your teeth.

I lernt at skool that I'm suposed to giv you milk as well as carots fur yur raindeers. I'll leeve them on the table so you can see them eezily.

Love from

Pierrot
}

Father Christmas removed any doubts I might have had by replying quickly:

\author{
My dear child, \\ Thank you for your lovely letter and list of gift requests. \\ I say, you are asking for rather a lot this year! Fortunately, my elves tell me that you have been a good \\ boy (except for a few small misdeeds... which I forgive you). \\ My elves and I are therefore busy preparing lots of wonderful surprises for you. But Ho-Ho-Ho! I hear \\ them calling me. I'll leave you there. I must help them prepare the presents. \\ Keep being a good little boy, working hard at school and making your parents happy. \\ I wish you a happy Christmas, my child. \\ Father Christmas
}

I immediately recognised his personal style: his jovial "Ho-Ho-Ho!"; his feigned indignation upon seeing my list of requests; but also his apparent pleasure in preparing lots of wonderful surprises for me; the paternally affectionate way he called me "my child"; his concern for my wellbeing, his interest in my schooling, and his consideration for my parents. Father Christmas looked out for me, he promised to shower me with surprises; and he kept his word: I remember the presents laid at the foot of the Christmas tree, my excitement unwrapping them and the joy I felt as I discovered the items I so desired. It is true that he made a few mistakes. He forgot the sweets, and the fire engine I received made no sounds (or it came without batteries, I'm not sure; all I remember is my father telling me it didn't make any sounds). But, after all, Father Christmas is a very busy 
old man; you couldn't blame him for making the odd mistake. And, as he once wrote, those few small misdeeds are forgiven.

Since then, every winter, I make it a point of pride to maintain our correspondence. For me, it has become sacred. To protect his letters, Mum bought me a small pirate chest like the ones you find on the stalls near your house on Main Street. It looked like it had been hewn from the finest wood, encircled in solid iron armour and made secure with an inviolable lock. It would have been a perfect imitation if it hadn't been for the childish picture on the cover: a young boy, dressed from head to toe in green and armed with a dagger, in a sword fight with a one-armed pirate, a caption commented on the battle with the words, "To live will be an awfully big adventure". I used that chest to carefully store the letters I received from my esteemed friend, as well as copies of my own letters. In times of sadness, and until quite recently, I used to open that treasure trove of correspondence, plunge back into our letters and find succour in my friend's words. I knew that somewhere out there in a cold land, someone was watching over me. A secret I learned to keep to myself.

At this point in my story, my friend, I have another confession to make: Father Christmas and I not only maintained regular correspondence, we also met on several occasions. This mostly happened at the shopping centre. Despite the crowds, and although he was solicited from all quarters, Father Christmas never failed to whisper kind words to me, ask me for the latest news or sit me up on his lap, but without ever revealing our secret relationship. I must admit that his discretion surprised me at first. Here, for example, is an incident I referred to in a letter sent at the age of 10, shortly before Christmas 199-

Father Christmas,

I hope all is well. I found you a bit strange when we saw one another. You couldn't remember my name.

You were thinner than usual. I hope you're not ill.

As for me, I've been very good. Ask your elves if you don't believe me.

Here's my list of presents: a Game Boy with games, the Lion King videotape as well as the music tape because it's really brilliant, pins of football teams and a remote-controlled car. I also want a dog (or a hamster), even though my dad doesn't. Sweets too, especially those that turn your tongue blue coz I never get to eat sweets coz mum says if I do I'll have to go to the dentist.

Will put out cakes for you coz I noticed you ate them all the last time.

Love from

Pierrot

As in previous years, I had met Father Christmas at the shopping centre, but he didn't seem to recognize me. He said he had forgotten my name, age and address and what he had given me the previous Christmas. I was very distressed. Was my old friend losing his mind? Was he rejecting me? It took me some time to understand. He preferred not to reveal our relationship. His mission meant he could not show any preference where I was concerned. His generosity had to have the appearance of impartiality. And so we invented a little ritual to deceive any onlookers. Whenever we met, Father Christmas and I pretended not to know one another but we exchanged a few knowing glances and complicit gestures and words. One day, for example, when he asked me my name I replied Hervé, and he went along with it and called me Hervé. On another occasion, he discreetly gave me a handful of sweets - the very ones he didn't dare leave at the foot of the tree, no doubt for fear of irking my mother. 
Our relationship continued to grow clandestinely. But as the years went by, Father Christmas's attitude changed. Our friendship even at times became a source of embarrassment. Here's a letter I wrote at the age of 18 , during the winter of 200-. I remember Mum insisting to read it, but I forbade her:

\footnotetext{
Hey Father C,

I hope you're well. Your elves have probably given you the latest updates... They're a bit of a dose, the way they spill the beans. I'm sure they're the ones who snitched on me to my old man about me puffing on Js with my mates. He slapped me one right in the kisser because of them. No joke! And imagine if my buddies get wise to your elves. What would I say to them?! That you send midgets in tights out to keep an eye on me?! Are you for real?! I guess you mean well, but I'm not six anymore!

Anyway, this year I'd like you to bring me a pair of Levi Strauss, the first volumes of the comic book Mauss and a skateboard (I enclose a photo of the exact model. You have to change the wheels. I also enclose a photo of the ones I want).

Later,

Pierre
}

His reply came swiftly:

My dear child,

Thank you for your lovely letter and list of gift requests.

I say, you are asking for rather a lot this year! Fortunately, my elves tell me that you have been a good boy (except for a few small misdeeds... which I forgive you).

My elves and I are therefore busy preparing lots of wonderful surprises for you. But Ho-Ho-Ho! I hear them calling me. I'll leave you there. I must help them prepare the presents.

Keep being a good little boy, working hard at school and making your parents happy.

I wish you a happy Christmas, my child.

Father Christmas

It was difficult for me to recognise this as my friend's style, in which condescendence had now replaced his benevolence and his concern had given way to surveillance. "My child...my dear child" ... was he unable to accept that I was growing up? I might only have been one-tenth his age, but I was nonetheless an adult. And that way he had of spying on my every move, monitoring my relationships and judging my actions. "A few small misdeeds"... could he not let me breathe and live my life? And how was I to react to a letter dashed off in that way, in between preparing two gift parcels? Could he not make his elves wait a while, to take time out to respond to his friend? But it didn't end there. Father Christmas had promised to shower me with surprises; but he didn't keep his word: I remember the presents laid at the foot of the Christmas tree, my excitement unwrapping them and the disappointment I felt as I discovered items that were of little interest to me. No skateboard, but instead roller-skates; and no comic book but instead a book by Dickens as reading material. Was Father Christmas playing a trick on me?

I told my girlfriend Ilona about my doubts. She seemed in no way surprised by my friend's conduct. Then she made fun of me, lending her support to the far-fetched conspiracy theories: Father Christmas didn't exist and was no more than a prop in a consumer society, the product of a commercial plot hatched by a well-known soda brand and supported by the entertainment industry, toy brands and stores, not to mention the guild of pastry chefs, the league of chocolatiers, the brotherhood of foie gras producers and even certain States such as Finland and Denmark, said to be 
the native lands of my famous friend. As you can see, my girlfriend had been misguided, trotting out the same old conspiracy theory ramblings: symbolic reasoning (the colour red being proof of the link between my eminent friend and a brand of soda), dubious geopolitical analysis (Scandinavian imperialism), revelation of a tyrannical social order (consumer society) and the existence of lobby groups manipulating the unsuspecting people (entertainment industry, brands, and stores). But one of my girlfriend's preferred tactics was to say, "walk around town just before Christmas and you will see not just one but many Father Christmases, proof that he is no more than a character played by several different actors". This theory is well-known, and it is made all the more formidable by the fact that it disguises a lie in a veil of truth: there are of course actors whowith varying degrees of talent - play the role of Father Christmas, just as there are actors who play the characters of Elvis Presley, Marilyn Monroe, and Michael Jackson; yet nobody would dream of denying that those celebrities actually existed. On this point, I feel it is pertinent to quote art historian Lester Nowak- " $a$ copy is testament to the original"-although it is preferable not to debate with conspiracy theorists in the first place.

I nonetheless decided to speak frankly with my friend. That winter, I wrote a letter describing my disappointment in the gifts Father Christmas had left for me:

\section{Dear Father Christmas,}

I hope this finds you well. Thank you for thinking of me once again last year. However, since we know each other so well, I feel I can allow myself this comment: while I really appreciate the effort you make in offering me gifts which I don't expect, frankly don't bother. You can just give me what appears in the list (that's what a list is for). I say this for your benefit. You're already busy enough as it is. You have to take it easy! You're no spring chicken anymore! Anyway, this year you can give me a PlayStation.

Really, keep it simple! Don't try to surprise me!

Take care of yourself.

Pierre

P.S. I broke up with Ilona. I was fed up with hearing Fiona, Fuat and her say that "Christmas sucks." But I guess your elves told you....

Father Christmas replied within a fortnight. I'll spare you the details of his letter-a bit paternalistic - which opened in a condescending manner, indicated that my misdeeds were forgiven and urged me to be virtuous. Father Christmas also promised to shower me with surprises; but he didn't keep his word: I remember the presents laid at the foot of the Christmas tree, my excitement unwrapping them and the disappointment I felt as I discovered items that were of little interest to me.

However, this was nothing compared to the drama that would unfold a few months later. Mum died in tragic circumstances, as you know. My father remarried within the year, abandoning my sister and me. When I realized that he was leaving us for his new wife, I slapped him. We never saw each other again. My little sister was just 6 years old. I interrupted my studies to get a job at the Park. That winter, I told my sister about my correspondence with Father Christmas, suggested introducing her to him and putting in a good word so she could get loads and loads of lovely presents. We wrote and posted the letter together:

Dear Father Christmas,

Hope you're well. My year has been a tough one. Your elves probably told you about my woes.

Here's my list: I'd like a new microwave (ours isn't working anymore) and a gift token for Virgin Megastore. Once again: no need to try and surprise me! Just follow the list! 
I'm writing this letter together with my little sister, Priscilla. She's nearly $6^{1 / 2}$ years old. She says to tell you that she really loves you, that she'd like a clown fish like in Finding Nemo, a Pokémon school bag, a witch's costume and sweets that it doesn't even matter if they get stuck in your teeth all the better. Lastly, don't worry, we'll do what we always did every year with Mum: we'll leave a glass of milk out on the table with some cake and carrots for your reindeer.

Hugs and kisses from the two of us,

Pierre \& Priscilla

P.S. Priscilla says you live with a bear who helps you get the gifts ready; that he is very clumsy, so much so that one day he destroyed your house. I said you had told me about your elves, but never about any bear and that I would know about him if he existed so it must be just a myth. Can you tell her as much in your own words please?

We didn't even have to wait a fortnight before Father Christmas replied:

My dear child,

Thank you for your lovely letter and list of gift requests.

I say, you are asking for rather a lot this year! Fortunately, my elves tell me that you have been a good boy (except for a few small misdeeds... which I forgive you).

My elves and I are therefore busy preparing lots of wonderful surprises for you. But Ho-Ho-Ho! I hear them calling me. I'll leave you there. I must help them prepare the presents.

Keep being a good little boy, working hard at school and making your parents happy.

I wish you a happy Christmas, my child.

Father Christmas

What an unsettling response! What about my little sister? Father Christmas took no notice of her. Work hard at school? I had to interrupt my studies. Make my parents happy? Mum is dead, and my dad is gone. Even more surprising was the fact that Father Christmas had promised to shower me with surprises; but he didn't keep his word: I remember my disappointment, bitterness and disquiet upon finding no presents laid at the foot of the Christmas tree. Was Father Christmas mocking me? Had he lost his mind? I didn't know what to say to Priscilla. I told her that Father Christmas had caught a chill and was forced to curtail his trip, but that we would be doubly spoiled the following Christmas.

I sent New Year's greetings to my old friend and enquired after his health. He didn't reply. I wrote to him again the following winter. He replied with a letter written in haste: he didn't have much time for us, but was preparing lots of wonderful surprises. We didn't receive a single one. It was the same story the following year, and the one after that.

I could see that Priscilla was saddened by the absence of gifts. What would you have done in my place, you who love children so much? As for me, I lied to her. I'm not proud of it. I'm even quite ashamed, for I make considerable efforts trying to convince her that my generous friend spoils her every year. My first subterfuge is to ask Priscilla to help me write my annual letter to Father Christmas; I even go so far as to make her post it. That way, I can see the list of what she wants. Another part of my strategy is to actually go out and buy the gifts she requests myself. At least then, Priscilla can wake to find presents laid at the foot of the Christmas tree, experience the excitement of unwrapping them and the joy of uncovering the items she so desires (except the sweets, which are bad for her teeth). And my last act of deception, every year, is to drink a glass of milk, eat some cake and discard a few carrots. But this is not enough for Priscilla, who is jealous of my privileged connection with Father Christmas. So I am now resigned to concocting the ultimate imposture: 
every Christmas, I leave a letter addressed to her by the fireplace, supposedly signed by my venerable friend. In it he tells of his adventures, talks of his elves and of their struggle against the goblins, and for Priscilla's pleasure, he mentions a very clumsy polar bear whom I have named Karhu. I sometimes include drawings. Last Christmas, for example, I enclosed one depicting the inside of Father Christmas's castle, with the master of the abode standing at the top of the great stairs raising his arms in exasperation; below him, at the very bottom of the stairs, lay the polar bear on his back with his four legs in the air, in a position that left no doubt: he had tripped and fallen down the steps one by one, scattering innumerable gifts.

Priscilla seemed content to go along with my machinations. I, on the other hand, was sad. My loyal companion continued to forget me each year. Sure, we would meet at the shopping centre, but I found him distant and he avoided eye contact and didn't speak much. His letters had also lost the benevolence of times gone by. The last one reproached me for "asking for rather a lot this year". Father Christmas was becoming stingy.

It was too much! I decided to deliver my letter to Father Christmas in person. I used to send it to the following address:

\section{Father Christmas}

Second Christmas tree to the right and straight on till the Aurora Borealis

North Pole

The address meant nothing to the travel agencies I visited. I was sent to a sparse little village in the north west of Finland called Enontekiö. A sign at the airport read: "Welcome to the True Lapland. Welcome to Santa's home." Elves came to greet me and showed me the way to Father Christmas's village, where I met some elves (I didn't expect them to be so tall) and reindeer (which, would you believe, don't eat carrots - at least not while working), but didn't encounter any polar bears (naturally!). I was expecting a warm welcome from my old acquaintance; I was disappointed and angered. Many people had travelled to visit him, so many indeed that I had to wait several hours before he would deign to receive me. Finally, later that evening, an elf drove me to Father Christmas's residence on a snowmobile. We travelled across a frozen lake and through a wood before following a candlelit path that led to his cabin. The elf invited me to enter. My friend, dressed in his red suit, was reclining in an old armchair near the fireplace, facing the door. The smell of gingerbread filled the room. We were alone. For the first time, we were free to chat like two old friends without having to fool any onlookers. I was emotional. I stammered out a timid greeting, to which he replied with a jovial "Ho-Ho-Ho! Hello my dear child!" I smiled. I approached to embrace my very dear friend, but stopped in my tracks when he spoke again.

He asked me my name, age, and address and what he had given me the previous Christmas. I thought it was some kind of joke. My host looked serious. I held my reserve. He asked if I had come alone, or perhaps with my children or parents. I didn't say a word. Why was he insisting on keeping up our little masquerade even though we were alone?

A creaking door broke the silence. Someone entered. It was Mother Christmas.

Upon my return, I wrote to my famous correspondent:

Dear Father Christmas,

You no longer visit me at Christmas, your letters lack their earlier warmth, you are becoming more distant each time we meet. I thought our friendship would never end, but I understand now that forever is a long, long time, and time has a way of changing things. You are turning your back on me and 
starting a new life with that woman. As for Priscilla and me, you have abandoned us. Very well! I wish you much happiness. I will bother you no longer.

Take care of yourself.

P. Ménard

That was my last letter to Father Christmas. He wrote me one final reply. In it he called me " $m y$ child" and "my dear child", as at the beginning, but his words lacked sincerity. Indeed, never again did he write to me after that, never again did he spoil me.

Forgive me if my story is a bit too long and sad. I wanted to tell it to you so you could understand my behaviour. Father Christmas was at the Park, speaking kind words to the children, asking after them and sitting them on his lap to sneak sweets into their hands. He spotted me but looked away. So I approached him and slapped the old hypocrite. The security guards grabbed me, and I was fired within the hour.

And so ends the happy times when Minnie, you, and I used to exchange the odd complicit and discreet nod, full of affection. I hope with all my heart that our wonderful friendship will survive this hardship. Continue to write to me.

With all my friendship,

Pierre M.

P.S. I almost forgot: I received your signed photo and your short inscription, "May all your dreams come true". Your encouragement means a great deal to me.

\section{Declaration of conflicting interests}

The author(s) declared no potential conflicts of interest with respect to the research, authorship, and/or publication of this article.

\section{Funding}

The author(s) received no financial support for the research, authorship, and/or publication of this article.

\section{ORCID iD}

Vivien Blanchet (D) https://orcid.org/0000-0003-1839-6501

\section{References}

Belk, R.W. (1989) 'Materialism and the Modern U.S. Christmas', in C. H. Elizabeth (ed) Interpretive Consumer Research. Provo, UT: Association for Consumer Research, pp. 75-104.

Brown, S., McDonagh, P. and Shultz, C.J. (2013) 'Titanic: Consuming the Myths and Meanings of an Ambiguous Brand', Journal of Consumer Research 40: 595-614.

Cluley, R. (2011) 'The Organization of Santa: Fetishism, Ambivalence and Narcissism', Organization 18(6): 779-94.

De La Ville, V.I. and Georget, A. (2014) Le Père Noël de la Poste. La surprenante histoire de son secrétariat (1962-2012). Bruxelles, Belgium: P.I.E. Peter Lang.

Eliade, M. (1954) The Myth of the Eternal Return: Cosmos and History. New York: Harper \& Row.

Favret-Saada, J. (1977) Les mots, la mort, les sorts. Paris, France: Gallimard.

Hancock, P. (2019) 'Organisational Magic and the Making of Christmas: On Glamour, Grottos and Enchantment', Organization. DOI: 10.1177/1350508419867205.

Hancock, P. and Alf, R. (2011) 'Organizing Christmas', Organization 18(6): 737-45. 
Lévi-Strauss, C. (1958) 'Le Père Noël supplicié', Les Temps Modernes 77: 1572-90.

Levy, S. J. (1981) 'Interpreting Consumer Mythology: A Structural Approach to Consumer Behavior', Journal of Marketing 45: 49-61.

Mauss, M. (1923) 'Essai sur le don forme et raison de l'échange dans les sociétés archaïques', L'Année sociologique 1(1): 30-186.

Mikkonen, I, Moisander, J. and Firat, A. F. (2011) 'Cynical Identity Projects as Consumer Resistance-the Scrooge as a Social Critic?', Consumption, Markets and Culture 14(1), 99-116.

Palo, T., Mason, K. and Roscoe, P. (2018) 'Performing a Myth to Make a Market: The Construction of the 'Magical World'of Santa', Organization Studies. DOI: 0170840618789192.

Thompson, C. J. (2004) 'Marketplace Mythology and Discourses of Power', Journal of Consumer Research 31: $162-80$.

Thompson, C. J. and Tian, K. (2008) 'Reconstructing the South: How Commercial Myths Compete for Identity Value through the Ideological Shaping of Popular Memories and Countermemories', Journal of Consumer Research 34: 595-613.

Vivien Blanchet is an associate professor of marketing at Emlyon Business School. He holds a PhD in organization studies from Paris-Dauphine University. His research focuses on the formation, performation, and transformation of sustainable markets (including fair trade, ethical fashion, and Base of Pyramid markets). He also interests in visual and discourse analysis. He coauthored a book on fair trade and published research articles in Organization, Marketing Theory, Journal of Macromarketing, and Recherche et Applications en Marketing. Address: Emlyon Business School, 23 Avenue Guy de Collongue, Ecully 69134, France. [email: vivien.blanchet@ext.emlyon.com] 